Jurnal Media Agribisnis Vol. 3 No. 2 Tahun 2018 Hal. 83 - 89

Media Komunikasi Hasil Penelitian Bidang Ilmu Agribisnis

ISSN print 2548-7027

ISSN online 2541-6898

\title{
KONTRIBUSI PENDAPATAN USAHA KOPRA TERHADAP PENDAPATAN RUMAH TANGGA PETANI DI KABUPATEN TANJUNG JABUNG TIMUR
}

\author{
Siti Abir Wulandari \\ Program Studi Agribisnis, Fakultas Pertanian Universitas Batanghari \\ Jl. Slamet Riyadi-Broni, Jambi. 36122. Tel. +6274160103 \\ email : Abir_wulandari@yahoo.com
}

\begin{abstract}
This research was conducted in East "Tanjung Jabung” District, Jambi Province. The purpose of this study was to determine the description of copra processing activities, to analyze the farmersincome, to find out the contribution of this income on farmer's household income. The population was copra farmers. In this study the sample was determined by the Multistage Sampling method. This research was conducted by survey method and its data was analyzed descriptively (both qualitative and quantitative). The results showed that the average income of copra farmers was Rp. 2,984,468.00 per month. The average contribution of copra farming income on the farmer's family income was $73.61 \%$.

Keyword: Contribution, Copra, Income, Farmer Household
\end{abstract}

\begin{abstract}
Abstrak
Penelitian ini dilakukan di Kabupaten Tanjung Jabung Timur Propinsi Jambi,Tujuan dari penelitian ini adalah untuk mengetahui gambaran kegiatan pengolahan kopra, menganalisis tingkat pendapatan petani kopra, mengetahui kontribusi pendapatan kopra terhadap pendapatan rumah tangga tani. Populasinya adalah petani kopra. Dalam penelitian ini sampel ditentukan dengan metode Multistage Sampling.Penelitian ini dilakukan dengan metode survey dan data dianalisis secara deskriptif (baik kualitatif maupun kuantitatif).Hasil penelitian menunjukkan bahwa rata-rata pendapatan petani kopra adalah sebesar Rp. 2,984.468,00 per bulannya. Rata-rata kontribusi pendapatan usahatani kopra terhadap pendapatan keluarga petani adalah $73,61 \%$.

Keyword: Kontribusi, Kopra, Pendapatan, Rumah Tangga Tani
\end{abstract}

\section{PENDAHULUAN}

Prospek agribisnis kelapa sangat baik dan mempunyai peluang yang tinggi dalam rangka memberdayakan ekonomi rakyat dan meningkatkan kesejahteraan masyarakat. Hilirisasi kelapa mulai dari buah, air kelapa, santan, sabut, tempurung dan lain-lain mestinya mampu mengembangkan ekonomi masyarakat, baik dalam bentuk peningkatan pendapatan maupun dalam hal penyerapan tenaga kerja demi terwujudnya kehidupan yang layak bagi keluarga petani kelapa. Namun potensi yang ada belum dapat dimanfaatkan secara maksimal sehingga belum mampu memberikan pendapatan yang mensejahterakan kehidupan petani.

Pengolahan buah kelapa tua bertujuan untuk meningkatkan nilai tambah dengan mengolah bahan menjadi produk baru atau memanfaatkan setinggi- 
Jurnal Media Agribisnis Vol. 3 No. 2 Tahun 2018 Hal. 83 - 89

Media Komunikasi Hasil Penelitian Bidang Ilmu Agribisnis

ISSN print 2548-7027

ISSN online 2541-6898

tingginya dan seefisien mungkin semua bagian produk kelapa yang dipanen. Pengolahan buah kelapa ini juga merupakan usaha penganekaragaman produk kelapa baik pada industri skala besar maupun kecil. Produk utama kelapa yang diandalkan sebagai sumber penghasilan petani dan negara adalah daging buah (meat, kernel, flesh). Daging buah merupakan bahan baku pembuatan kopra.

Dalam rangka meningkatkan pendapatan petani kopra, perlu adanya usaha yang kongkrit sehingga program pembangunan pertanian dapat mencapai sasaran yaitu meningkatkan produksi, meningkatkan pendapatan petani dan akhirnya dapat meningkatkan kesejahteraan bagi petani dan keluarganya dari hasil usahanya.

Tujuan penelitian ini adalah untuk mengetahui gambaran kegiatan pengolahan kopra, menganalisis dan mengetahui kontribusi pendapatan kopra terhadap pendapatan rumah tangga petani kopra di Kabupaten Tanjung Jabung Timur.

\section{METODOLOGI PENELITIAN}

Penelitian ini dilakukan di Kabupaten Tanjung Jabung Timur Propinsi Jambi. Dipilihnya Kabupaten Tanjung Jabung Timur ini dengan pertimbangan bahwa kabupaten ini merupakan kabupaten dengan luas tanam dan produksi kelapa dalam tertinggi di Propinsi Jambi yang diikuti usahatani kopra. Adapun yang menjadi fokus kajian dalam penelitian ini adalah pada pendapatan petani kopra dan kontribusinya terhadap pendapatan rumah tangga petani kopra.

Jenis data berdasarkan sakal waktu yang digunakan dalam penelitian ini adalah cross section, jenis data berdasarkan skala pengukuran adalah data rasio. Data yang dikumpulkan bersumber dari data primer dan data sekunder. Data primer adalah data yang dikumpulkan dari sumber data pertama. Data primer diperoleh melalui survey lapangan dan wawancara terhadap para responden di Kabupaten Tanjung Jabung Timur. Data sekunder merupakan data penunjang data primer yang diperoleh dari instansi terkait berupa laporan, jurnal-jurnal penelitian, dan publikasi yang mendukung penelitian ini. Data sekunder dikumpulkan dengan menggunakan studi kepustakaan.

Pengambilan sampel dilakukan dengan metode Multistage Sampling. Tahap pertama, yaitu penetapan kecamatan sampel. Pemilihan wilayah Kecamatan dilakukan secara purposive berdasarkan kecamatan yang menghasilkan kopra tertinggi. Kecamatan yang terpilih adalah Kecamatan Mendahara dan Kecamatan Muara Sabak Timur . Tahap kedua pemilihan wilayah desa pada masing-masing kecamatan juga dilakukan secara Purposive berdasarkan desa yang menghasilkan kopra tertinggi sehingga diperoleh dua desa yaitu Desa Simbur Naik dan Desa Mendahara Ilir. Responden dalam penelitian ini adalah petani yang melakukan usahatani kopra di daerah penelitian.

Menurut Winarno (1994), bila populasi cukup homogen, terhadap populasi dibawah 100 dapat digunakan sampel sebesar 50\%, bila populasi diatas 100 dapat diambil sampel sebesar $15 \%$, dan juga sampel manusia hendaknya diatas 30 orang besarnya. Dari 250 orang populasi petani kopra diambil 60 orang sebagai sampel 
Jurnal Media Agribisnis Vol. 3 No. 2 Tahun 2018 Hal. 83 - 89

Media Komunikasi Hasil Penelitian Bidang Ilmu Agribisnis

ISSN print 2548-7027

ISSN online 2541-6898

dengan teknik pengambilan sampel secara acak sederhana (simple random sampling).

Data yang diperoleh disederhanakan dengan cara tabulasi dan persentase, kemudian dianalisis secara deskriptif. Untuk mengetahui penggunaan input dan biaya produksi yang digunakan dalam usaha kopra dianalisis secara deskriptif, untuk menghitung besarnya jumlah total biaya produksi dengan cara menjumlahkan total biaya tetap atau total fixed cost (TFC), ditambah total biaya tidak tetap atau total variable cost (TVC) sesuai dengan rumus Sudarman dan Algifari (2001) :

$T C=T F C+T V C$

Keterangan:

$\mathrm{TC}=$ Total Cost atau Total Biaya (Rp/Bulan).

TFC = Total Fixed Cos tatauTotal Biaya Tetap (Rp/Bulan).

TVC =Total Variabel Cost atauTotal Biaya Variabel (Rp/Bulan).

Untuk menghitung besarnya penerimaan ditentukan dengan menggunakan rumus sebagai berikut ( Samuelson dan Nordhaus, 2003):

$T R=P q . Q$

Keterangan:

$\mathrm{TR}=$ Total Revenue atau Total Penerimaan ( $\mathrm{Rp} / \mathrm{Bulan})$.

$\mathrm{Pq} \quad=$ Price atau Harga Produk $(\mathrm{Rp} / \mathrm{Kg})$.

$\mathrm{Q} \quad=$ Quantity atau Jumlah Produksi kering/ basah (Kg/Bulan).

Untuk menghitung besarnya biaya penyusutan alat digunakan rumus (Syafri, 2002). Dengan asumsi harga akhir alat sebesar nol :

$\mathrm{D}=\frac{\mathrm{P}-\mathrm{S}}{\mathrm{N}}$

Keterangan:

$\mathrm{D}=$ Biaya Penyusutan Alat (Rp/Bulan).

$\mathrm{P} \quad=$ Harga awal alat $(\mathrm{Rp})$.

$\mathrm{S} \quad=$ Harga akhir alat (Rp).

$\mathrm{N} \quad=$ Perkiraan Umur Ekonomis (Bulan). Asumsi $S=0$

Untuk mengetahui pendapatan diperoleh dengan cara mengurangkan total penerimaan dengan total biaya, dengan rumus sebagai berikut (Suratiyah, 2006):

$I=T R-C$

Keterangan:

I = Income atau Pendapatan (Rp/Bulan).

$\mathrm{TR}=$ Total Revenue atau Total Penerimaan (Rp/Bulan).

$\mathrm{TC}=$ Total Cost atau Total Biaya (Rp/Bulan).

Sedangkan untuk mengetahui besarnya kontribusi pendapatan dari usahatani kopra terhadap total pendapatan rumah tangga petani dihitung dengan menggunakan rumus: 
Jurnal Media Agribisnis Vol. 3 No. 2 Tahun 2018 Hal. 83 - 89

Media Komunikasi Hasil Penelitian Bidang Ilmu Agribisnis

ISSN print 2548-7027

ISSN online 2541-6898

$K=\frac{\text { Pdi }}{\text { Tpa }} \times 100 \%$

Dimana:

$\mathrm{K}=$ Kontribusi pendapatan usahatani terhadap pendapatan total rumah tangga $(\%)$.

Pdi = Pendapatan usahatani kopra (Rp/Bulan).

Tpa $=$ Total pendapatan rumah tangga petani $(\mathrm{Rp} / \mathrm{Bulan})$.

\section{HASIL DAN PEMBAHASAN \\ Gambaran Kegiatan Usahatani Kopra Di Daerah Penelitian}

Kopra di tingkat petani berasal dari kelapa yang sudah dipanen dari kebun sendiri kemudian dilansir dan dikumpulkan di gudang penyimpanan.Kemudian kelapa tersebut diproses melalui tahap pengupasan dari sabut, lalu kelapa dibelah menjadi dua bagian lalu dikeringkan/dijemur dibawah sinar matahari selama kurang lebih 1 hari.Setelah itu kelapa tersebut dicungkil lalu dimasukkan kedalam karung kemasan berisi 50kg untuk kemudian dijual ke pabrik maupun melalui pedagang pengumpul. Adapun peralatan dan bahan-bahan yang digunakan pada kegiatan produksi ini yaitu berupa baji, alat pencungkil, parang, dan tikar. Modal untuk melaksanakan kegiatan usaha kopra ini berasal dari pinjaman oleh petani kopra.

Untuk pengolahan kelapa menjadi kopra dibutuhkan waktu dan biaya yang mahal.Hal inilah yang menyebabkan petani kopra banyak yang tidak melaksanakan kegiatan pengolahan kopra dengan baik seperti menjemur dibawah matahari maupun pengasapan.Kopra yang bermutu tinggi harus dalam keadaan kering dan bersih. Kopra dapat dikeringkan dengan menjemur di bawah terik matahari maupun melalui pengasapan. Pengeringan dengan sinar matahari membutuhkan waktu sekitar 5 sampai 7 hari untuk mendapatkan hasil yang maksimal. Sedangkan apabila melakukan pengasapan, waktu yang dibutuhkan sedikit dan lebih cepat yaitu sekitar 3 hari.

Sebagian besar petani kopra di Kabupaten Tanjung Jabung Timur melakukan pengolahan kelapa menjadi kopra tanpa melanjutkannya ke proses pengeringan dan pengolahan minyak kelapa. Petani kopra mengolah 2-3 butir buah kelapa untuk menghasilkan $1 \mathrm{~kg}$ kopra.

Pada aspek pemasaran, untuk harga kopra basah, dijual dengan harga ratarata Rp. $3.780 / \mathrm{kg}$. Kopra yang dijual petani dikemas menggunakan karung plastik kemasan $50 \mathrm{~kg} / \mathrm{karung}$. Adapun cara pemasaran kopra yang dilakukan yaitu sebagian besar dijual melalui pedagang pengumpul namun ada beberapa orang petani kopra menjual langsung ke pabrik pengolahan kopra di wilayah Jambi. Untuk sistem pembayaran dilakukan secara tunai sesuai dengan perjanjian yang telah disepakati. 
Jurnal Media Agribisnis Vol. 3 No. 2 Tahun 2018 Hal. 83 - 89

Media Komunikasi Hasil Penelitian Bidang Ilmu Agribisnis

ISSN print 2548-7027

ISSN online 2541-6898

\section{Biaya Produksi Usahatani Kopra}

Biaya Produksi adalah total biaya yang digunakan dalam proses produksi yang terdiri dari biaya tetap dan biaya tidak tetap. Biaya tetap adalah biaya yang dikeluarkan dalam proses produksi yang tidak habis dalam satu kali produksi atau biaya yang besarnya tidak dipengaruhi besarnya produksi. Biaya tidak tetap adalah biaya yang digunakan dalam proses produksi dan habis dipakai dalam satu kali proses produksi atau biaya yang besarnya dipengaruhi oleh besarnya produksi (Suratiyah, 2006).

Pada usahatani kopra yang diusahakan petani, penggunaan biaya tetap adalah biaya penyusutan yang dihitung berdasarkan nilai ekonomis alat. Penyusutan atau depresiasi adalah pengalokasian harga perolehan dari suatu aktiva tetap karena adanya penurunan nilai aktiva tetap tersebut. (Amalia D, 2017). Adapun alat yang digunakan yang terdiri dari baji, alat pencungkil, parang dan tikar. Sedangkan biaya tidak tetap terdiri dari biaya tenaga kerja, transportasi dan biaya pembelian karung.

Biaya produksi untuk usahatani kopra di daerah penelitian yang terbesar adalah komponen biaya tidak tetap. Biaya tidak tetap terendah adalah sebesar 129.500 per bulan dan biaya tidak tetap tertinggi adalah sebesar Rp. 807.500 per bulan. Rata-rata biaya tidak tetap per bulannya adalah sebesar Rp. 712.372. Komponen terbesar penggunaan biaya tidak tetap adalah untuk transportasi dan komponen terendah biaya tidak tetap adalah biaya tenaga kerja. Biaya tetap terendah adalah sebesar Rp 102.500 per bulan dan biaya tetap tertinggi sebesar Rp. 670.000 per bulan dengan rata-rata biaya tetap sebesar Rp. 215.980 per bulan. Selanjutnya dilihat dari jumlah komponen biaya tetap tersebut, yang paling besar digunakan rata-rata untuk biaya tikar yaitu sebesar 166.250 per bulan dan ratarata penggunaan biaya tetap terkecil untuk alat pencukil yaitu sebesar Rp. 2.507 per bulan.

\section{Penerimaan Usahatani Kopra}

Penerimaan adalah nilai produk dalam jangka waktu tertentu baik yang dijual maupun yang tidak dijual (Soekartawi dkk, 2000) Secara umum petani mengharapkan penerimaan yang diperoleh dari kegiatan usahataninya akan selalu lebih besar dari biaya yang telah dikeluarkan dalam usahatani tersebut. Semakin besar penerimaan yang diperoleh maka akan termotivasi untuk mempertahankan bahkan meningkatkan produksinya. Sama halnya dengan kegiatan produksi lainya yang berorientasi ekonomis, dihasilkan serta harga jual per satuan produksi (Hernanto, 1996). Penerimaan usahatani kopra adalah nilai uang yang diterima dari penjualan kopra yang merupakan perkalian antara jumlah produksi kopra dengan harga kopra itu sendiri. Rata-rata penerimaan usahatani kopra di daerah penelitian adalah sebesar Rp. 3.696.840,00 per bulannya. Besarnya penerimaan tergantung dari harga saat hasil produksi dijual. Harga terendah penjualan kopra didaerah penelitian sebesar Rp. 3.000/kg dan harga tertinggi penjualan kopra dari petani sebesar Rp. 4.000/kg, serta rata-rata harga penjualan kopra sebesar Rp. $3.780 / \mathrm{kg}$. Produksi kopra terendah sebanyak $225 \mathrm{~kg} / \mathrm{bulan}$ dan produksi tertinggi sebanyak $1.500 \mathrm{~kg} / \mathrm{bulan}$ dengan rata-rata produksi sebanyak $978 \mathrm{~kg} / \mathrm{bulan}$ 
Jurnal Media Agribisnis Vol. 3 No. 2 Tahun 2018 Hal. 83 - 89

Media Komunikasi Hasil Penelitian Bidang Ilmu Agribisnis

ISSN print 2548-7027

ISSN online 2541-6898

\section{Pendapatan Usahatani Kopra}

Setiap usahatani membutuhkan input untuk menghasilkan output, sehingga produksi yang dihasilkan akan dinilai secara ekonomis berdasarkan biaya yang dikeluarkan dan penerimaan yang diperoleh. Selisih keduanya merupakan pendapatan dar kegiatan usahatani. Pendapatan ini dianggap sebagai balas jasa untuk faktor-faktor produksi yang digunakan (Brown, 1979). Pendapatan usahatani kopra adalah selisih antara penerimaan dengan biaya produksi usahatani kopra. Pendapatan terendah petani kopra sebesar Rp. 473.000 per bulannya, pendapatan tertinggi sebesar Rp. 5.139 .583 per bulan. Rata-rata pendapatan petani kopra di daerah penelitian adalah sebesar Rp. 2,984.468 per bulannya. Adapun rata-rata biaya produksi sebesar Rp. 712.372 perbulan dengan biaya produksi terendah sebesar Rp. 282.083 perbulannya dan biaya produksi tertinggi perbulannya sebesar Rp. 1.350.000.

\section{Pendapatan Sampingan Petani Kopra}

Selain berusahatani kopra petani juga masih mampu melakukan usahatani lain yang bisa menambah pendapatan selain usahatani kopra. Pendapatan sampingan tersebut diperoleh dari usaha pinang dan batok kelapa. Rata-rata pendapatan sampingan petani kopra di daerah penelitian sebesar Rp. 1.069.833,00 per bulan. Pendapatan sampingan terendah sebesar Rp. 690.000 per bulannya dan pendapatan sampingan tertinggi sebesar Rp. 1.830.000 per bulan. Pendapatan total tertinggi petani sebesar Rp. 6.827 .500 per bulannya dan pendapatan total petani terendah sebesar Rp. 1.163 .000 per bulan serta rata-rata pendapatan total petani sebesar Rp. 4.054.301 per bulan.

\section{Kontribusi Pendapatan Usahatani Kopra Terhadap Pendapatan Rumah Tangga Petani}

Kontribusi dalam pengertian sebagai tindakan yaitu berupa prilaku yang dilakukan oleh individu yang kemudian memberikan dampak baik positif maupun negatif terhadap pihak lain ( Anneahira, 2012). Kontribusi pendapatan usahatani kopra adalah besarnya sumbangan yang diberikan oleh usahatani kopra ke dalam pendapatan total keluarga petani yang dinyatakan dalam persentase (\%). Rata-rata kontribusi pendapatan usahatani kopra terhadap pendapatan keluarga petani di daerah penelitian adalah sebesar $73,61 \%$ dimana kontribusi pendapatan usahatani kopra terendah adalah sebesar 40,64\% dan kontribusi pendapatan usahatani kopra tertinggi adalah sebesar $87,91 \%$. Hal ini memperlihatkan bahwa sumber pendapatan terbesar rata-rata diperoleh dari usahatani kopra. Dari hasil ini terlihat bahwa pendapatan usahatani kopra memberikan kontribusi yang cukup besar terhadap pendapatan keluarga petani. 
Jurnal Media Agribisnis Vol. 3 No. 2 Tahun 2018 Hal. 83 - 89

Media Komunikasi Hasil Penelitian Bidang Ilmu Agribisnis

ISSN print 2548-7027

ISSN online 2541-6898

\section{KESIMPULAN}

Kopra yang merupakan hasil pengeringan daging kelapa, dan banyak diusahakan oleh masyarakat Indonesia sebagai bahan baku pembuatan minyak kelapa.Konsumsi kopra dalam pasar internasional dikelompokkan ke dalam sektor industri (bahan baku), karena kopra tidak dapat dikonsumsi langsung oleh konsumen akhir tetapi harus diubah menjadi Crude Coconut Oil (CCO), yang kemudian diubah menjadi minyak goreng, bahan baku oleokimia untuk pembuatan sabun, kosmetik, dan lain sebagainya. Pemanfaatan produk samping seperti sabut dan tempurung belum banyak dilakukan.Sebagian besar petani kelapa dalam di Kabupaten Tanjung Jabung Timur melakukan pengolahan kelapa menjadi kopra tanpa melanjutkannya ke proses pengeringan dan pengolahan minyak kelapa. Dalam $1 \mathrm{~kg}$ kopra membutuhkan biji kelapa sebanyak 2-3 buah kelapa, sedangkan bila diolah menjadi minyak membutuhkan 7-9 biji kelapa per liternya. Produksi minyak yang dilakukan petani untuk memenuhi kebutuhan sendiri dan untuk pasar lokal bisa dicapai dengan harga yang cukup lumayan. Rata-rata pendapatan petani kopra di daerah penelitian adalah sebesar $\mathrm{Rp}$. 2,984.468,00 per bulannya. Rata-rata kontribusi pendapatan usahatani kopra terhadap pendapatan keluarga petani di daerah penelitian adalah sebesar 73,61\%

\section{DAFTAR PUSTAKA}

Anneahira, 2012. Pengertian Pendidikan. http://anneahira.com/arikel-pendidikan. Diakses tanggal 22 Februari 2018.

Amalia D, 2017. Metode Penyusunan Aktiva Tetap dalam Akuntansi. https://www.jurnal.id.sdn.ampproject.org Diakses tanggal 26 Februari 2018.

Brown, M.I., 1979. Farn budgets : from farm income analyzing to agricultural project analysis. The jhones Hopkin Universiy press. Baltimore and London.

Hernanto, F, 1996. Ilmu Usahatani. Penebar Swadaya. Jakarta

Samuelson dan Nordhaus, 2003. Ilmu Mikro Ekonomi. Media Global Edukasi. Jakarta.

Soekartawi, 2000. Panduan Membuat Usaha Proyek Pertanian dn Pedesaan. Andi. Yogyakarta.

Sudarman dan Algifari, 2001. Ekonomi Makro-Mikro. BPFE, Yogyakarta.

Suratiyah K, 2006. Ilmu Usahatani. Penebar Swadaya, Jakarta.

Syafri, 2002. Akuntansi Aktiva Tetap. Bumi Aksara. Jakarta.

Winarno,1994. Pengantar Penelitian Ilmiah (dalam metode teknik). Kanisius, Bandung. 